\title{
Different expression levels of $\alpha 3 / 4$ fucosyltransferases and Lewis determinants in ovarian carcinoma tissues and cell lines
}

\author{
C. ESCREVENTE ${ }^{*}$, E. MACHADO ${ }^{1 *}$, C. BRITO ${ }^{1}$, C.A. REIS ${ }^{2}$,

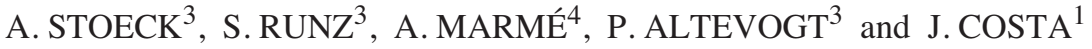 \\ ${ }^{1}$ Instituto de Tecnologia Química e Biológica, Apartado 127, 2781-901 Oeiras; ${ }^{2}$ IPATIMUP - \\ Institute of Molecular Pathology and Immunology of the University of Porto, Rua Dr. Roberto Frias, s/n, \\ 4200-465 Porto, Portugal; ${ }^{3}$ Tumor Immunology Programme, D010, German Cancer Research Center; \\ ${ }^{4}$ Department of Obstetrics and Gynecology, University of Heidelberg, Heidelberg, Germany
}

Received February 22, 2006; Accepted April 14, 2006

\begin{abstract}
Ovarian carcinoma is the leading cause of death from gynecological cancers in many countries. Fucosylated glycoconjugates have been associated with various carcinomas. In the present study, we have characterized the expression of $\alpha 3 / 4$ fucosyltransferases transcripts and their products, the Lewis carbohydrate determinants, and their in vitro specificity towards synthetic acceptors using ovarian carcinoma cell lines OVM, m130, GG and SKOV3. We found different expression patterns: GG cells expressed mostly Lewis ${ }^{\mathrm{x}}\left(\operatorname{Le}^{\mathrm{x}}\right)$, Lewis ${ }^{\mathrm{y}}\left(\mathrm{Le}^{\mathrm{y}}\right)$, $\mathrm{SLe}^{\mathrm{a}}$ and $\mathrm{Le}^{\mathrm{b}}$, and m130 cells expressed mostly $\mathrm{Le}^{\mathrm{x}}$ and $\mathrm{Le}^{\mathrm{y}}$. The detection was on the plasma membrane and in intracellular vesicles. OVM and SKOV3 cells had very low amounts of staining. From RT-PCR studies, enzyme specificity of cellular extracts towards a panel of synthetic carbohydrate acceptors and Western blot analysis we concluded that Le ${ }^{\mathrm{a}}$, sLe $e^{\mathrm{a}}$ and $\mathrm{Le}^{\mathrm{b}}$ were synthesised by FUT3, whereas $\mathrm{Le}^{\mathrm{x}}$ and $\mathrm{Le}^{\mathrm{y}}$ were synthesized by FUT4 and FUT9 in both cell lines. The GG and m130 cell lines are adequate models to investigate the role of $\mathrm{Le}^{\mathrm{x}}, \mathrm{Le}^{\mathrm{y}}, \mathrm{sLe}^{\mathrm{a}}$ and $\mathrm{Le}^{\mathrm{b}}$ in ovarian carcinoma development.
\end{abstract}

\section{Introduction}

Ovarian carcinoma is the leading cause of death from gynecological cancers in many Western countries. Primary ovarian cancers can be classified according to the structure of the ovary from which they derived. The majority, 80-90\%, develop from epithelial cells (serous, mucinous, endometrium and mixed),

Correspondence to: Dr Júlia Costa, Instituto de Tecnologia Química e Biológica, Avenida da República, Apartado 127, 2781901 Oeiras, Portugal

E-mail: jcosta@itqb.unl.pt

${ }^{*}$ Contributed equally

Key words: ovarian cancer, fucosyltransferase, Lewis determinant followed by carcinomas originating in granulosa cells or, rarely, in the stroma cells (reviewed in ref. 1).

Fucosylated glycoconjugates have been associated with various cancers. An increase in the carbohydrate determinants

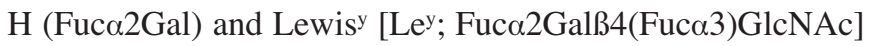
expression concomitant to a decrease of A and B blood group antigens for several tumors, in correlation with a poor prognosis has been observed. Furthermore, increases of sialyl-Lewis ${ }^{x}$ [sLe ${ }^{\mathrm{x}}$; NeuAc $\alpha 2,3 \mathrm{Gal} 34$ (Fuc $\alpha 3$ )GlcNAc] and sialyl-Lewis ${ }^{\mathrm{a}}$ [sLe ${ }^{a}$; NeuAc $\alpha 2,3 \mathrm{Gal} 33$ (Fuc $\alpha 4$ )GlcNAc] were also found to be associated with disease progression and bad prognoses. $\mathrm{sLe}^{\mathrm{x}}$ and $\mathrm{sLe}^{\mathrm{a}}$ are ligands of E- and P-selectin and may aid in hematogenous metastasis (reviewed in ref. 2). Expression of the carbohydrate determinants sialyl Tn, TF, Le ${ }^{\mathrm{y}}$, Globo $\mathrm{H}$ and GM2 have been associated with ovarian cancer, and a vaccine against this type of cancer using as antigen Ley-keyhole limpet haemocyanin has undergone clinical phase I (reviewed in ref. 3).

The $\alpha 3 / 4$ fucosyltransferases (FTs) are key enzymes that regulate the synthesis of Lewis carbohydrate determinants and constitute a group of FTs with a high degree of sequence similarity. $\alpha 3 / 4$ FTs catalyse the transfer of fucose from GDPfucose to one or more acceptor substrates in an $\alpha 1,3$ or $\alpha 1,4$ linkage to GlcNAc in Gal-GlcNAc sequences type I, Gal B3GlcNAc-R (Le ${ }^{\mathrm{a}}, \mathrm{Le}^{\mathrm{b}}, \mathrm{sLe}^{\mathrm{a}}$ ), or type II, Galß4GlcNAc-R $\left(\mathrm{Le}^{\mathrm{x}}, \mathrm{Le}^{\mathrm{y}}, \mathrm{sLe}^{\mathrm{x}}\right)$. Eight $\alpha 3$ FTs have been identified in the human genome at present. FUT3, the Lewis enzyme, predominantly synthesizes $\alpha 4-$ and to a lesser extent $\alpha 3$ fucosylated oligosaccharides with the resulting products $\mathrm{Le}^{\mathrm{a}}$, $\mathrm{Le}^{\mathrm{b}}, \mathrm{sLe}^{\mathrm{a}}, \mathrm{Le}^{\mathrm{x}}, \mathrm{sLe}^{\mathrm{x}}, \mathrm{Le}^{\mathrm{y}}(4)$. Myeloid FUT4 is an $\alpha 3 \mathrm{FT}$ and synthezises Le ${ }^{\mathrm{x}}$ and Le ${ }^{\mathrm{y}}(5)$. FUT5 and FUT6 synthesize Le and $\operatorname{sLe}^{\mathrm{x}}(6,7)$ although some reports have shown that FUT5 can also produce Le ${ }^{a}(8)$. FUT7 can only synthesize sLe ${ }^{\mathrm{x}}(9)$. FUT9 synthesizes Le ${ }^{\mathrm{x}}(10)$. FUT10 and FUT11 have been identified from the human genome since they have a conserved a3 FT domain (11), however their activity has not been validated (12).

Several reports demonstrated fucosyltransferases neoexpression or upregulation in human tumours that are not normally expressed or only expressed in low levels in the corresponding normal tissue. In lung cancer the expression of 
FUT4 and FUT7 genes is related to poor prognosis (13). FUT4 was also observed to be significantly increased in gastric and colorectal carcinoma $(14,15)$. FUT6 mRNA expression was detected specifically in pancreatic cancer tissues (16) and invasive as well as non-invasive bladder carcinoma cell lines (17), but not in normal pancreas or bladder.

Human ovarian carcinomas have been also described with several-fold higher levels of $\alpha 3$ and $\alpha 4$ FTs, compared with normal ovarian tissue (19), however, the identity of the specific enzymes is still not clear.

Ovarian cancer is often asymptomatic in the earlier stages and patients are only diagnosed after metastatic spread within the peritoneal cavity and/or distant organs. The characterization of the Lewis determinants and identification of the FTs associated with carcinoma development might provide means of establishing a specific diagnostic and prognostic.

In the present work, we have determined the expression pattern by RT-PCR of $\alpha 3 / 4$ FTs in four ovarian carcinoma cell lines, SKOV3, OVM, m130 and GG, and ovarian carcinoma tissues. We also analysed the expression of $\mathrm{Le}^{\mathrm{a}}$, $\mathrm{sLe}^{\mathrm{a}}, \mathrm{Le}^{\mathrm{b}}, \mathrm{Le}^{\mathrm{x}}, \mathrm{sLe}^{\mathrm{x}}$ and $\mathrm{Le}^{\mathrm{y}}$ carbohydrate determinants, specificities and Western blot analysis of FTs from the different cell extracts. We have found that GG followed by m130 cells expressed the higher amounts of Lewis determinants, and identified that FUT3 synthesized $\mathrm{Le}^{\mathrm{a}}$, sLe ${ }^{\mathrm{a}}$ and $\mathrm{Le}^{\mathrm{b}}$ in GG cell line whereas FUT4 and FUT9 synthesized Le ${ }^{\mathrm{x}}$ and Le ${ }^{\mathrm{y}}$ in both cell lines.

\section{Materials and methods}

Cell culture. SKOV3, OVM, m130 and GG ovarian carcinoma cell lines, as well as BHK-21B cells, were grown in Dulbecco's modified Eagle's medium (DMEM; Sigma), supplemented with $10 \%$ (v/v) fetal calf serum, 100 units $/ \mathrm{ml}$ penicillin, $0.1 \mathrm{mg} / \mathrm{ml}$ streptomycin (Invitrogen). Cells were grown in a humidified incubator at $37^{\circ} \mathrm{C}$ in a $5 \% \mathrm{CO}_{2}$ atmosphere.

Tissue samples. Patient material was obtained under the approval of the ethics committee of the University of Heidelberg. Diagnoses were established by conventional clinical and histological criteria according to the World Health Organization (WHO). The classification of tumor tissues was as follows: tissue 1, serous ovarian carcinoma pT3c G3 R2; tissue2, serous papillary ovarian carcinoma pT3c G3 R2; tissue 3 , serous papillary ovarian carcinoma pT3c G3 R2; tissue 4, serous papillary ovarian carcinoma pT3c G2 R3; tissue 5, serous ovarian carcinoma pT3c G3 R3; tissue 6, serous ovarian carcinoma pT3c G3 R1; tissue 7, mucinous ovarian carcinoma pT3c G2 R2; tissue 8, serous adenocarcinoma of the fallopian tube pT3c G3 R1; tissue 9, serous ovarian carcinoma pT3c G3 R1; and tissue 10, serous papillary adenocarcinoma of both ovaries pT3c G2 R2. Gx represents tumor grade.

$R T-P C R$. Total RNA was isolated from cultured cells using the Rneasy mini kit (Qiagen), following the manufacturer's instructions. RNA concentration and quality were determined spectrophotometrically.

The reverse transcription reaction contained $0.1 \mu \mathrm{g} / \mu \mathrm{l}$ RNA, $60 \mathrm{ng} / \mu 1$ random hexamers (Invitrogen), $10 \mathrm{mM}$ dNTPs
(Amersham), cDNA synthesis buffer, 0.1 M DTT and 200 units of M-MLV reverse transcriptase (Invitrogen) in $20 \mu 1$ reaction. RNA and random hexamers were denatured for $5 \mathrm{~min}$ at $65^{\circ} \mathrm{C}$ followed by primer extension at $25^{\circ} \mathrm{C}$ for $10 \mathrm{~min}$. cDNA synthesis was accomplished at $37^{\circ} \mathrm{C}$ for $50 \mathrm{~min}$ and reaction was inactivated by incubation at $70^{\circ} \mathrm{C}$ for $15 \mathrm{~min}$.

Frozen sections from ovarian carcinoma tissues contained $>90 \%$ tumor cells as revealed by hematoxilin/eosin staining of adjacent sections. Fifteen sections $(10 \mu \mathrm{m})$ were used to isolate mRNA using the Qiagen RNAeasy kit as descibed above.

PCR amplification of all genes studied, was carried out in $25 \mu \mathrm{l}$ reaction containing buffer, $1.5 \mathrm{mM} \mathrm{MgCl}, 0.2 \mathrm{mM}$ dNTPs (Amersham) and 2.5 units Taq polymerase (Invitrogen). Portions of $\alpha 3 / 4$ FTs from human ovarian cancer cell lines and tumoral tissues were amplified using specific primers that can discriminate among them, despite their high homology (Fig. 1). PCR conditions were as follows: $1 \mu 1 \mathrm{cDNA}$ template for FUT4 to FUT7, FUT9 to FUT11, and $\beta$-actin or $2 \mu 1$ FUT3; $0.25 \mu \mathrm{M}$ or primers for FT5, FUT11, and $\beta$-actin, or $0.4 \mu \mathrm{M}$ for FUT3, FUT4, FUT6, FUT7, FUT9 and FUT10. For FUT4 5\% dimethylsulfoxide was added. The specific PCR conditions consisted of the following steps: pre-denaturation at $94^{\circ} \mathrm{C}$ for $5 \mathrm{~min}$; 30 cycles of denaturation at $94^{\circ} \mathrm{C}$ for $45 \mathrm{sec}$, annealing at $64^{\circ} \mathrm{C}$ for $1 \mathrm{~min}$ for FUT3, FUT4, FUT6 and FUT7, or at $72^{\circ} \mathrm{C}$ for $2 \mathrm{~min}$ for FUT5, or $57^{\circ} \mathrm{C}$ for $45 \mathrm{sec}$ for FUT9, or $55^{\circ} \mathrm{C}$ for $45 \mathrm{sec}$ for FUT10 and FUT11, and extension at $72^{\circ} \mathrm{C}$ for $2 \mathrm{~min}$, and a final extension step at $72^{\circ} \mathrm{C}$ for $7 \mathrm{~min}$. Positive controls for FUT3, FUT4 and FUT7 were performed using as template the plasmid vectors pCRFT3 (20), pCR3FT4 and pCR3FT7, respectively (21). To ensure primer specificity, all FT sequences were aligned using ClustalW program and cDNA regions with lower similarity were found for primer design. The primers were aligned with known nucleotide sequences using the NCBI BLAST program, and it was confirmed that they were specific for their respective FTs.

In order to control the cDNA integrity and to check for a possible contamination with genomic DNA, B-actin, a housekeeping gene, was amplified. For the reaction $0.25 \mathrm{mM}$ of each primer, forward 5'-gatatcgccgcgctcgtcgtcgac-3' and reverse 5'-caggaaggaaggctggaagagtgc-3', were used (22). PCR conditions were as above except that 25 cycles were performed and the annealing temperature was $61^{\circ} \mathrm{C}$ for $1 \mathrm{~min}$. Reaction products were separated by electrophoresis with $1.5 \%$ agarose, stained with ethidium bromide for $10 \mathrm{~min}$ and visualized under a UV lamp. In order to confirm the specificity of the amplification a typical fragment from FUT10 of all cell lines was sequenced. The fragments were purified with QIAquick gel extraction kit, from Qiagen, and analysed by automated DNA sequencing.

Immunofluorescence microscopy. Cells grown on glass coverslips to $\sim 80 \%$ confluency, were washed with phosphatebuffered saline (PBS) containing $0.5 \mathrm{mM} \mathrm{MgCl}$, fixed with $4 \%(\mathrm{w} / \mathrm{v})$ paraformaldehyde in PBS for $20 \mathrm{~min}$, and nonpermeabilized or permeabilized with $0.1 \%(\mathrm{w} / \mathrm{v})$ Triton $\mathrm{X}$ 100 for $15 \mathrm{~min}$. Fixed cells were blocked with $1 \%$ of bovine serum albumin (BSA) in PBS for $1 \mathrm{~h}$, followed by incubations at room temperature for 2 and $1 \mathrm{~h}$ with primary and secondary antibodies, respectively. Antibodies were diluted in PBS 

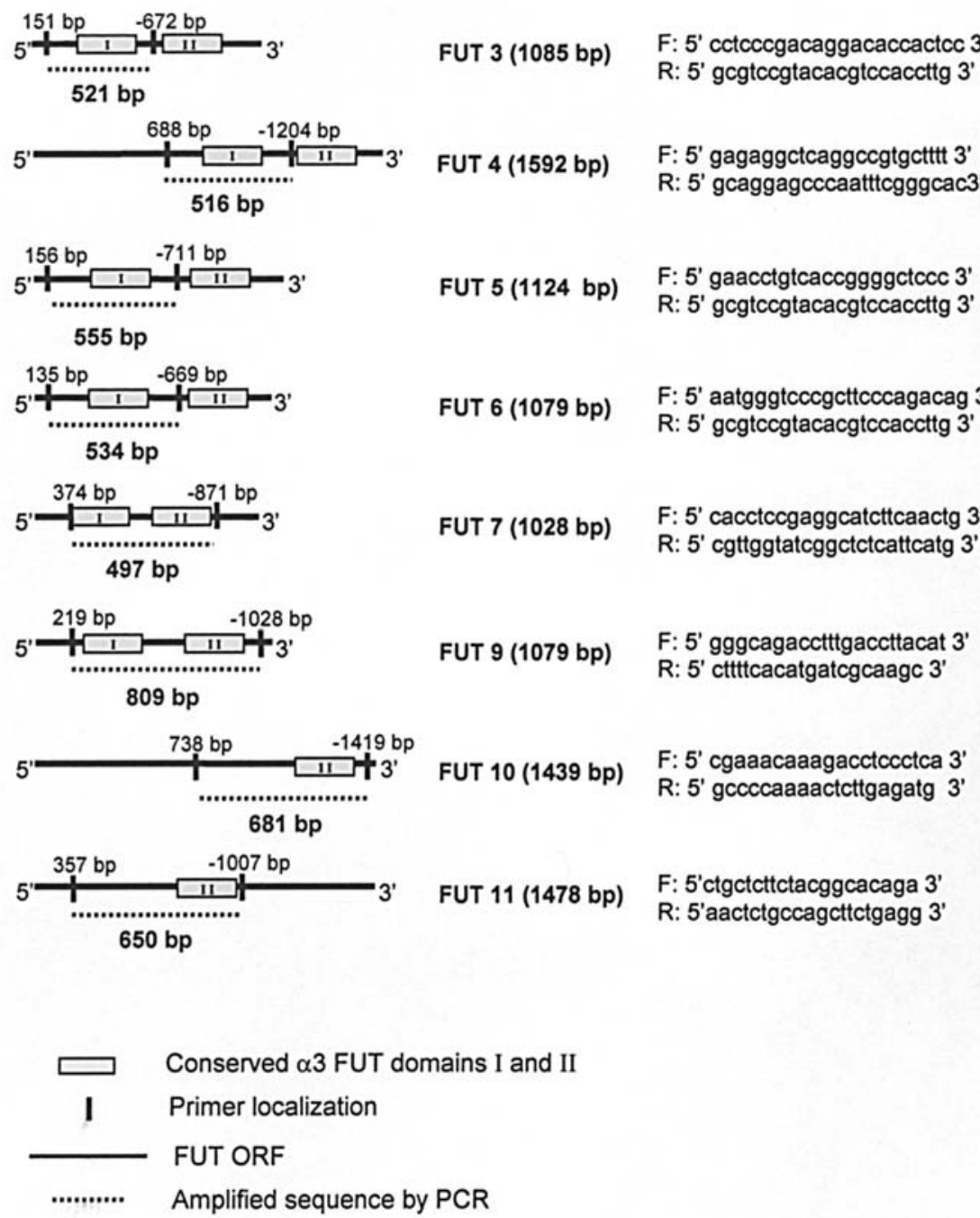

Figure 1. Localization of reverse and forward primers in the indicated $\alpha 3 / 4$ FTs cDNA sequences. Primer sequences are shown on the right. Primers for FUT3-FUT7 have been described by Numahata et al (17), primers for FUT9-FUT11 have been designed by us using the Primer3 software. Sequences have been aligned with ClustalW program and boxes I and II correspond to $\alpha 3$ FT domains as previously defined by Breton et al (18). Primers are specific for individual FTs as confirmed by NCBI BLAST program.

containing $1 \%$ or $2 \% \mathrm{BSA}$, and washes were performed with PBS. The primary antibodies used were: mouse IgG anti-Le PR5C5 (Biogenesis) and mouse IgM anti-Le ${ }^{\mathrm{b}}$ BG-6 (Signet Laboratories) at 1:40 dilution in 1\% BSA in PBS; hybridoma supernatants mouse IgG anti-sLe ${ }^{\text {a }}$ CA19-9, mouse IgG antiLe $^{\mathrm{x}}$ SH1 (23), mouse IgM anti-sLe ${ }^{\mathrm{x}}$ FH6 (24) twenty-fold concentrated, mouse IgM anti-Le ${ }^{y}$ AH6 (25), and mouse IgM anti-Le ${ }^{\mathrm{x}}$ SSEA-1 (MC-480) (DSHB, University of Iowa, USA) at $1: 1$ dilution in $2 \%$ BSA in PBS. The secondary antibodies used were: goat anti-mouse IgM tetramethylrhodamine Bisothiocyanate (TRITC) conjugate (Sigma) and donkey antimouse IgG Alexa 594 (Invitrogen) at 1:64 and 1:500 dilution in $1 \%$ BSA in PBS, respectively. Coverslips were mounted in Airvol and examined with a Leica DMRB microscope. Images were acquired using a COHU high performance CCD camera coupled to the microscope and Leica QFISH software, with exposure times of 300 to $500 \mathrm{msec}$ and 1000 to $1500 \mathrm{msec}$.

FACS analysis. The staining of cells with saturating amounts of mAbs, either hybridoma supernatants or purified antibodies, and phycoerithrin-conjugated goat antibodies to mouse immunoglobulins has been described (26). Stained cells were analyzed with a FACScan cell analyzer (Becton-Dickinson, Heidelberg, Germany) using Cellquest software (BectonDickinson).

SDS-PAGE and Western blot analysis. Protein extracts were obtained by solubilization of centrifuged cells in RIPA buffer [50 mM Tris- $\mathrm{HCl} \mathrm{pH} 7.5,150 \mathrm{mM} \mathrm{NaCl}, 0.1 \%$ SDS, $1 \%$ sodium deoxycholate (DOC), 1\% Triton X-100, 1/50 Complete protease inhibitor cocktail tablets (Roche)]. Protein concentration was determined by the bicinchoninic acid method. For fucosyltransferase detection, protein extracts from $1 \times 10^{6}$ cells from each carcinoma cell line were used. Proteins were precipitated with 4 volumes of absolute ethanol, denatured by boiling in SDS-PAGE sample buffer and detected by Western blot analysis. Polyvinyledene difluoride (PVDF) membranes were blocked with $5 \%$ defatted dry milk (Nestle) in PBS with $0.1 \%$ Tween-20 before the addition of antibodies. The following primary antibodies were used: affinity purified antiserum anti-FUT3 SA-4817 at $0.4 \mu \mathrm{g} / \mathrm{ml}$ (27), C-20 antiFUT4 and N-18 anti-FUT5 at 1:1000 dilution, C-20 antiFUT9 at 1:500 dilution in blocking solution, obtained from Santa Cruz Biotechnology. The secondary antibodies used 


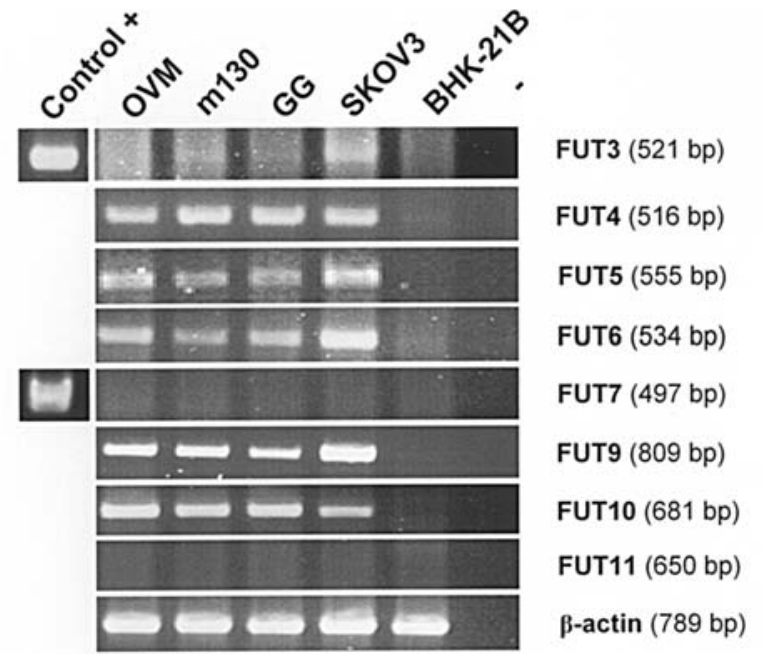

Figure 2. RT-PCR analysis of fucosyltransferases FUT3 to FUT7 and FUT9 to FUT11 from ovarian carcinoma cell lines. B-actin was used as control. cDNA was obtained from ovarian carcinoma cell lines OVM, m130, GG, SKOV3, and the control cell line BHK-21B that does not express peripheral fucosyltransferases. After PCR reaction, products were separated on $1.5 \%$ agarose gel and their size estimated relatively to a gene ruler $1 \mathrm{~kb}$ and $100 \mathrm{bp}$ DNA ladders. The sizes of the amplified fragments are indicated on the right.

were: anti-rabbit IgG coupled to horseradish peroxidase (Amersham Pharmacia Biotech) at 1:3000 dilution and antigoat IgG coupled to horseradish peroxidase (Sigma) at 1:15000 dilution in blocking solution. Bands were visualized according to the ECL Plus method (Amersham Pharmacia Biotech).

Glycoprotein detection using lectins. Glycoproteins were stained after transfer to PVDF membrane with lectins. Glycoproteins with affinity for concanavalin A (Con A), peanut agglutinin (PNA) and Sambuccus nigra lectin (SNA) were detected essentially according to Faye and Chrispeels (28). PNA was covalently linked to horseradish peroxidase (PNAHRP; Sigma). Con A (Sigma) specifically binds HRP in the presence of $\mathrm{Ca}^{2+}$ and $\mathrm{Mg}^{2+}$. SNA was biotinylated (Vector Laboratories). Briefly, the glycoproteins were fixed on the PVDF membrane by incubation with $25 \%$ 2-propanol and $10 \%$ acetic acid for $5 \mathrm{~min}$. The membrane was blocked for $1 \mathrm{~h}$ with TBS containing $0.5 \mathrm{M} \mathrm{NaCl}$ and $0.1 \%$ Tween-20 (TTBSc), incubated overnight with $10 \mu \mathrm{g} / \mathrm{ml}$ of lectin PNAHRP, or $1 \mathrm{~h}$ with $25 \mu \mathrm{g} / \mathrm{ml}$ Con A. The Con A membrane was washed and further incubated for $1 \mathrm{~h}$ with HRP type I (Sigma). Incubations with the lectins and washings were performed with TTBSc for PNA-HRP, and with TTBSc containing $1 \mathrm{mM} \mathrm{CaCl}_{2}$ and $1 \mathrm{mM} \mathrm{MgCl}$ for Con A/HRP. Development was performed with $0.5 \mathrm{mg} / \mathrm{ml}$ 4-chloro-1naphtol and $8.3 \times 10^{-3} \% \mathrm{H}_{2} \mathrm{O}_{2}$ in PBS. For SNA, the membrane was blocked for $1 \mathrm{~h}$ with TBSc containing $2 \%$ bovine serum albumin, incubated with $5 \mu \mathrm{g} / \mathrm{ml}$ of lectin SNA-biotin, followed by $2 \mu \mathrm{g} / \mathrm{ml}$ streptavidin-peroxidase (Sigma) in blocking buffer. Development was as above.

Fucosyltransferase activity. Fucosyltransferase activity was measured by the incorporation of radioactive fucose from the GDP- $\left[{ }^{14} \mathrm{C}\right]-$ Fucose donor (Amersham Pharmacia Biotech) into

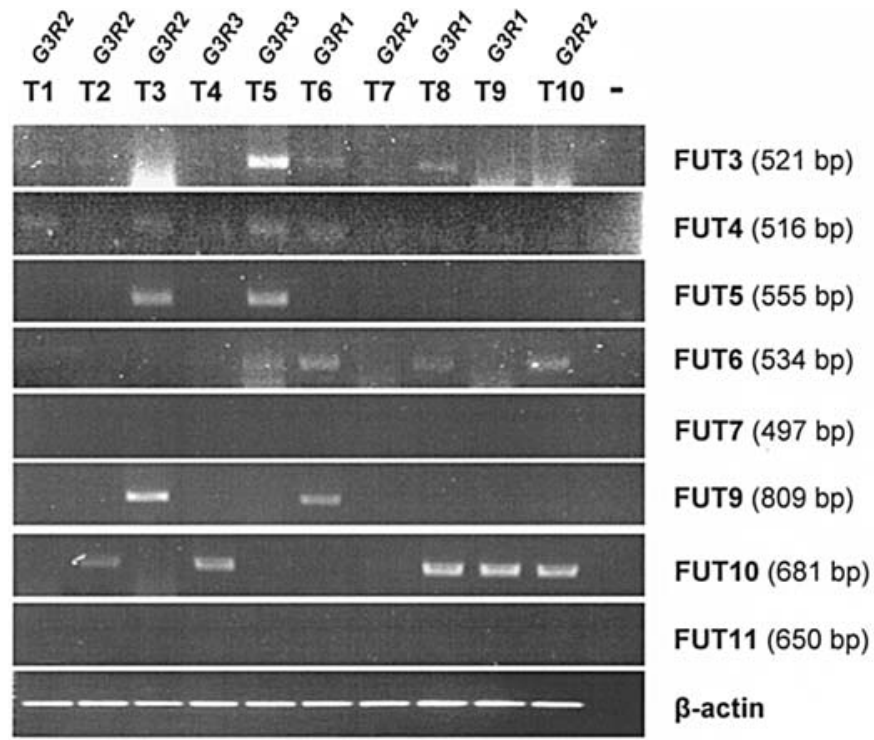

Figure 3. RT-PCR analysis of fucosyltransferases FUT3 to FUT7 and FUT9 to FUT11 from ovarian carcinoma tissues. $\beta$-actin was used as control. cDNA was obtained from serous ovarian carcinoma tissues T1, T5, T6 and T9, serous papillary ovarian carcinoma tissues T2, T3 and T4, mucinous ovarian carcinoma tissue $\mathrm{T} 7$, serous adenocarcinoma of the fallopian tube tissue T8, and serous papillary adenocarcinoma of both ovaries tissue T10. The progression grade of the tumors is indicated at the top. After PCR reaction, products were separated on $1.5 \%$ agarose gel and their size estimated relatively to a gene ruler $1 \mathrm{~kb}$ and $100 \mathrm{bp}$ DNA ladders. The sizes of the amplified fragments are indicated on the right.

several acceptors as previously described (27). The acceptors used were: type I, Galß3GlcNAc-R, NeuAca2,3Galß3GlcNAc$\mathrm{R}$ and Fuc $22 \mathrm{Gal} 3 \mathrm{GlcNAc-R}$ (H type I); type II, Galß4GlcNAc-R (LacNAc), NeuAc $\alpha 2,3$ Galß4GlcNAc-R (sialyl-LacNAc) and Fuc 2 Galß4GlcNAc-R (H type II) (Lectinity Holding). The acceptors were linked to a hydrophobic spacer arm where $\mathrm{R}=-\left(\mathrm{CH}_{2}\right)_{3}-\mathrm{NHCO}-\left(\mathrm{CH}_{2}\right)_{5}-\mathrm{NH}-$ biotin. One unit of enzyme activity was defined as the amount of enzyme catalysing the transfer of $1 \mu \mathrm{mol}$ of Fuc/min to the acceptor.

\section{Results}

Fucosyltransferase mRNA expression in ovarian carcinoma cell lines and tissues. RT-PCR analysis was performed on the ovarian carcinoma cell lines SKOV3, OVM, m130 and GG to characterize the expression pattern of the $\alpha 3 / 4$ FTs in these cells. BHK-21B cells were used as a negative control since they do not express any peripheral FT. Total RNA was isolated from the different cell lines and the cDNA synthesized with M-MLV reverse transcriptase using random hexamers.

We observed the specific amplification of fragments from FUT4 (516 bp), FUT5 (555 bp), FUT6 (534 bp), FUT9 (809 bp), and FUT10 (681 bp) for all cell lines analysed (Fig. 2). Only small amounts of FUT3 fragment (521 bp) were observed predominantly in SKOV3 cells, followed by GG and m130 even if there was a strong amplification in similar conditions from the plasmid pCRFT3 coding for FUT3. These results suggested that a lower amount of FUT3 mRNA was present in those cells. There was no amplification of FUT7 although the primers could amplify the expected band 

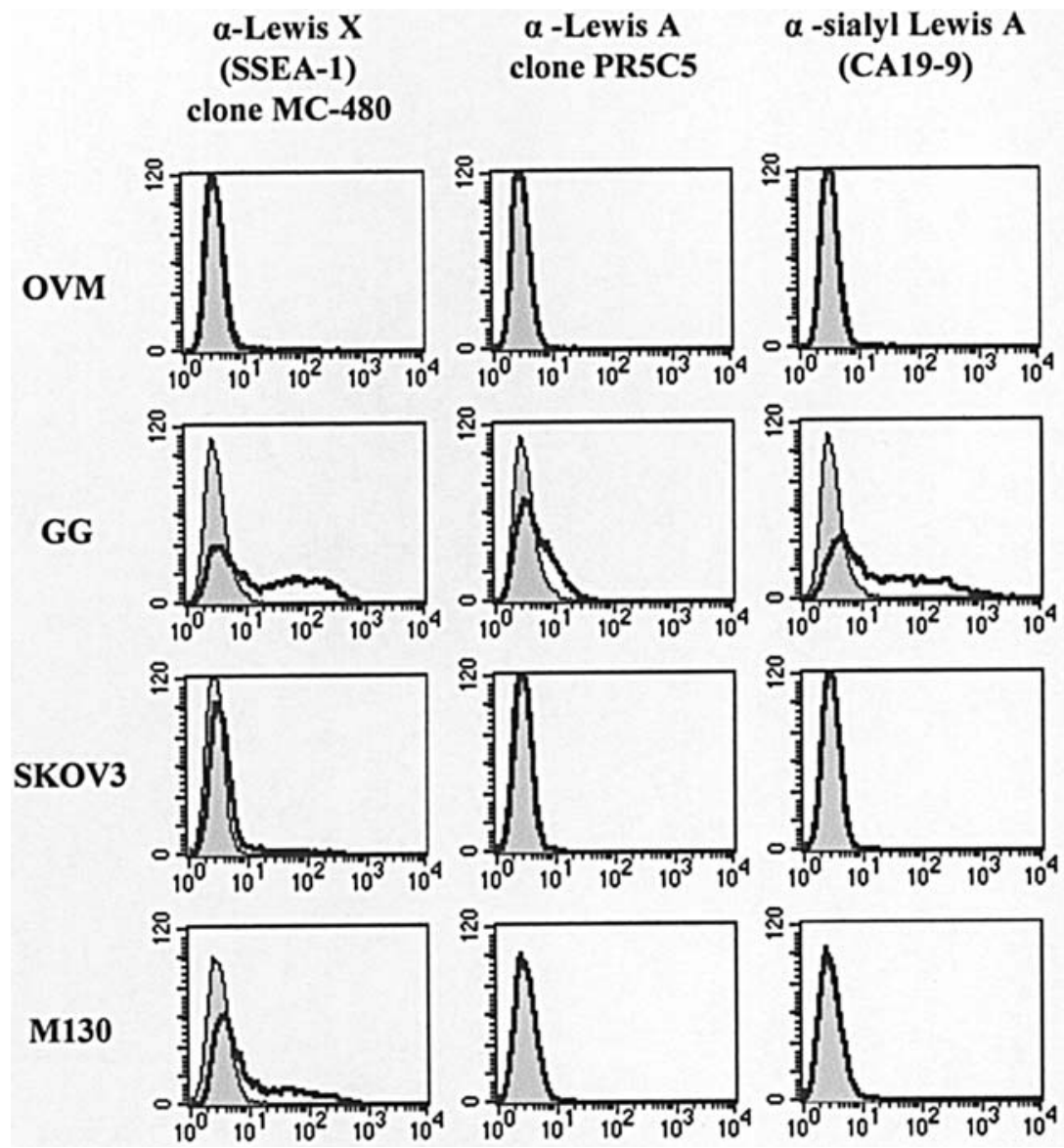
$\alpha$-sialyl Lewis X clone FH6
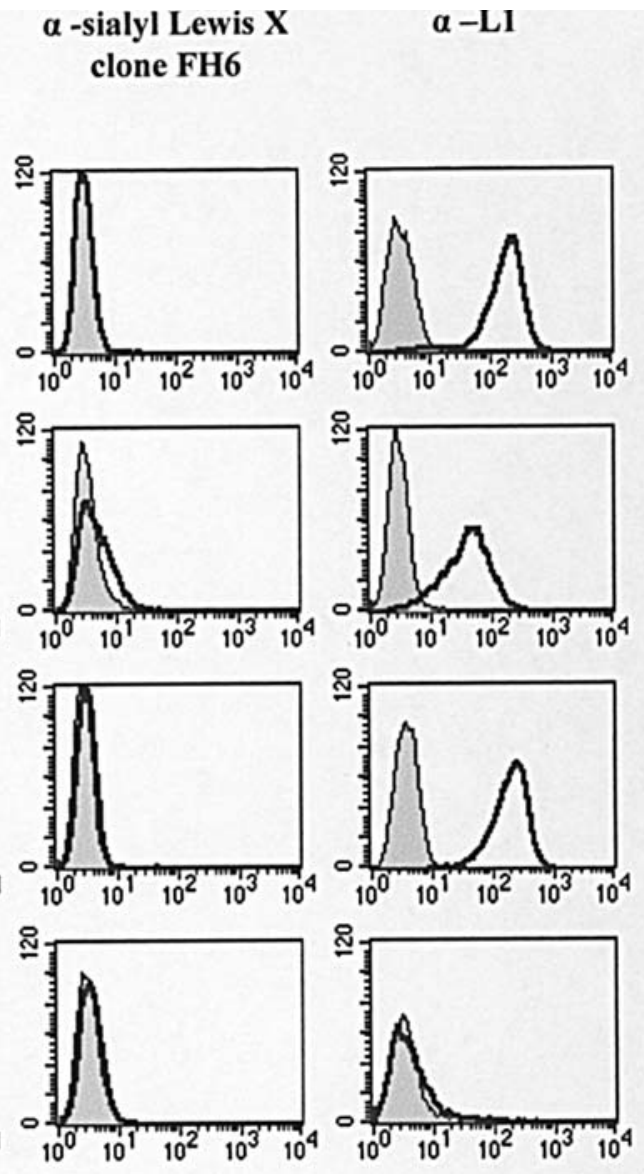

Figure 4. FACS analysis of ovarian carcinoma cells for cell surface expression of carbohydrate epitopes. Cells were incubated with primary antibody followed by phycoerithrin-conjugated secondary antibody.

in similar conditions from plasmid DNA pCR3FT7 coding for FUT7 (21).

No amplification of any of the studied FTs was observed in BHK-21B cells as expected. Amplification of $ß$-actin (789 bp), used as a positive control for the RT-PCR experiment showed similar intensities for all cell lines, suggesting that amplifications were performed on comparable amounts of cDNA except for FUT3 where double the amount of template was used.

We next examined the expression pattern of $\alpha 3 / 4$ FTs in ovarian carcinoma tissues of different types: serous ovarian carcinoma (SOC), serous papillary ovarian carcinoma (SPOC), mucinous ovarian carcinoma (MOC), serous adenocarcinoma of the fallopian tube (SAFT) and serous papillary adenocarcinoma (SPA) of both ovaries (Fig. 3). We observed the expression of FUT3 in samples of SOC (T5 and T6) and SAFT (T8). FUT4 was detected in SOC (T1, T5 and T6) and SPOC (T3 and T4). FUT5 was expressed in one sample of SPOC (T3) and another of SOC (T5). FUT6 was found in SOC (T5, T6), SAFT (T8) and SPA (T10). FUT9 was detected in one sample of SPOC (T3) and another of SOC (T6). Finally, FUT10 was found in five samples, two SPOC (T2, T4), one SAFT (T8), one SOC (T9) and one SPA (T10).

Interestingly, from the two tissues examined with a lower grade of progression only one expressed a single FT: FUT6. On the other hand, FUT4 was more extensively represented in tissues with a higher grade of progression.
Expression of carbohydrate Lewis determinants on human ovarian carcinoma cells. The expression of fucosylated carbohydrates on the surface of ovarian carcinoma cells was determined by FACS analysis (Fig. 4). The GG cell line exhibited the higher level of the cell surface carbohydrate epitopes $\mathrm{Le}^{\mathrm{x}}, \mathrm{Le}^{\mathrm{a}}, \mathrm{sLe}^{\mathrm{a}}$ and $\mathrm{sLe}{ }^{\mathrm{x}}$. The cell line m130 followed by SKOV3 had small amounts of surface Le ${ }^{x}$. The OVM cell line did not show any of the fucosylated epitopes studied. As a control, the cell surface adhesion molecule L1 was detected for the cell lines studied. L1 was found in high amounts on the surface of OVM and SKOV3 cells, followed by GG cells with lower amounts as expected from previous studies (26).

The expression of intracellular as well as surface Lewis determinants was also determined by immunofluorescence microscopy for all cell lines and additional antibodies anti-Le ${ }^{b}$ and anti-Le ${ }^{y}$ were used. Discrimination between plasma membrane and plasma membrane/intracellular staining was accomplished by the comparison of non-permeabilized vs. permeabilized cells. GG cells contained predominantly sLe ${ }^{a}$, $\mathrm{Le}^{\mathrm{b}}, \mathrm{Le}^{\mathrm{x}}$ and $\mathrm{Le}^{\mathrm{y}}$ (Fig. 5E, F, A, and C) but almost undetectable amounts of $\mathrm{Le}^{\mathrm{a}}$ and $\mathrm{sLe}^{\mathrm{x}}$ (Fig. 5D and B). These epitopes were detected on the cell surface (corresponding to FACS detection) where interesting morphological formations consisting of numerous plasma membrane projections were visualized (Fig. 5E, inset). The same epitopes were also detected in intracellular vesicles (Fig. 5A, C, E, and F). Additionally, SSEA-1-stained GG cells showed staining 


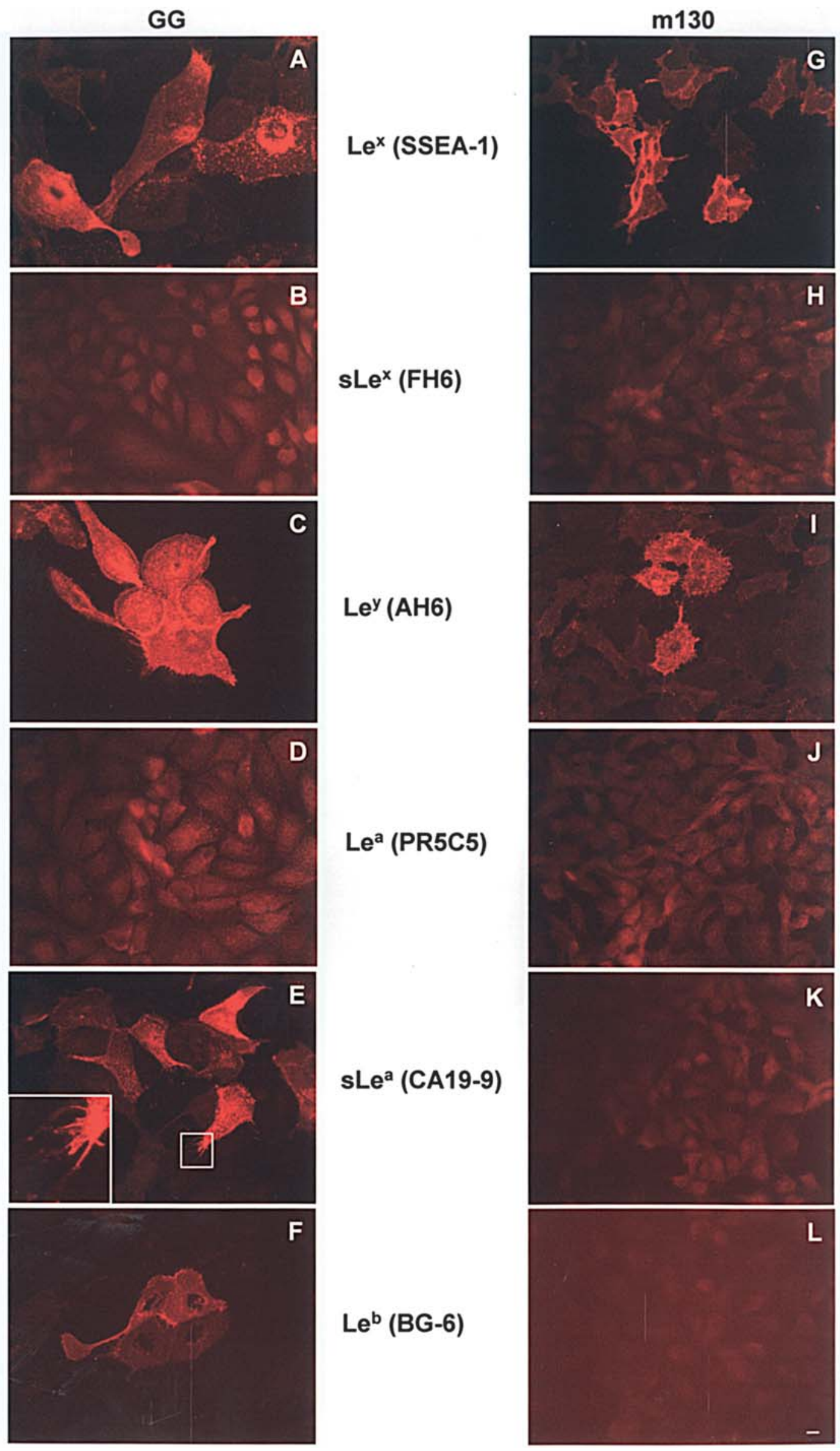

Figure 5. Immunofluorescence microscopy of Lewis carbohydrate determinants from GG and m130 ovarian carcinoma cells. GG and m130 cell lines were fixed with $4 \%$ paraformaldehyde and permeabilized with $0.1 \%$ Triton X-100. Cells were probed with antibodies anti-Le PR5C5, anti-sLe ${ }^{\mathrm{a}}$ CA19-9, anti-Le ${ }^{\mathrm{b}}$ BG-6, anti-Le ${ }^{x}$ SSEA-1, anti-sLe ${ }^{x}$ FH6 and anti-Le ${ }^{y}$ AH6. Secondary antibodies were anti-mouse IgG ALEXA 594 or anti-mouse IgM TRITC conjugate. Images A, C, E, F, G and I were acquired with 300 to $500 \mathrm{msec}$, images D, H, L, K and J were acquired with 1000 to $1500 \mathrm{msec}$. of exposure. Scale bar, $10 \mu \mathrm{m}$. 


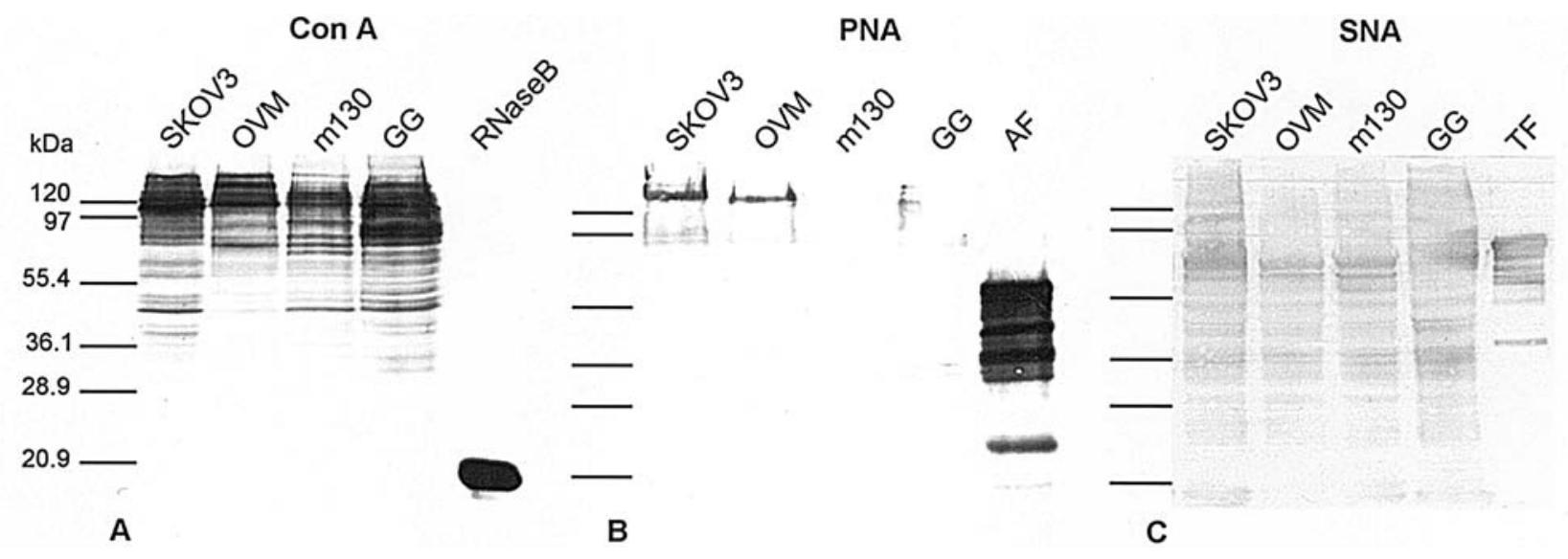

Figure 6. Immunodetection by Western blotting of glycoproteins in ovarian carcinoma cell lines. Sixty $\mu \mathrm{g}$ of protein were applied per lane in a $12 \%$ acrylamide gel. Detection was performed using lectin Con A (A), PNA (B) and SNA (C). Two $\mu \mathrm{g}$ of RNaseB, asialofetuin (AF) and $1 \mu \mathrm{g}$ of transferrin were applied as positive controls (indicated above the lanes).

around the nucleus with a morphology characteristic of the Golgi apparatus (Fig. 5A).

M130 cells showed high amounts of Ley (Fig. 5I) followed by $\mathrm{Le}^{\mathrm{x}}$ (Fig. 5G). Also in these cells stained plasma membrane projections and intracellular vesicles were detected (Fig. 5G and I). The other determinants were only detected in residual amounts.

For both GG and m130 cell lines we have also observed $\mathrm{Le}^{\mathrm{x}}$ with the monoclonal antibody $\mathrm{SH} 1$ (results not shown). $\mathrm{SH} 1$ is capable of recognizing $\mathrm{Le}^{\mathrm{x}}$ in short type 2 chains (29) whereas anti-SSEA-1 has a narrower specificity and requires that $\mathrm{Le}^{\mathrm{x}}$ is present in a long poly-N-acetylactosamine backbone (30). Therefore, at least a part of the $\mathrm{Le}^{\mathrm{x}}$ from GG and $\mathrm{m} 130$ cells is present in long poly-N-lactosamine chains.

SKOV3 followed by OVM cells expressed low amounts of intracellular $\mathrm{Le}^{\mathrm{x}}$ in few cells, and almost undetectable amounts of Le (data not shown).

Lectin-binding properties of human ovarian carcinoma cells. In order to detect glycosylation profiles of ovarian carcinoma cells, we also performed Western blot analysis of cellular extracts followed by lectin binding, and immunofluorescence microscopy with specific carbohydrate-binding antibodies.

We observed that the amount of Con A-binding polypeptides was higher for GG cells and lower for OVM cells (Fig. 6A). Since Con A binds $\alpha$-mannosyl containing-branched oligosaccharides predominantly from oligomannose-type followed by hybrid- and biantennary complex-type structures (31), the results indicated the predominance of this type of structure in GG cells. As positive control ribonuclease B has been used since it contains oligomannose type oligosaccharides (32).

PNA that is specific for Galß3GalNAc from $O$-linked oligosaccharides strongly bound one glycoprotein with mass higher than $120 \mathrm{kDa}$ from SKOV3 cells, also found in lower amounts in OVM followed by GG cells but undetectable in m130 cells (Fig. 6B). As positive control for PNA binding asialofetuin was used $(33,34)$.

SNA specific for terminal NeuAc $\alpha 2,6 \mathrm{Gal}$ or NeuAc $\alpha 2$, 6GalNAc, and to a lesser extent terminal NeuAca2,3-linked, predominantly bound GG and SKOV3 cells followed by
OVM and m130 cells (Fig. 6C). As positive control for SNA binding human plasma transferrin was used that contains peripheral NeuAca2,6-linked (35). Collectively, the results showed ovarian carcinoma cell type-specific glycosylation.

Fucosyltransferase activities of human ovarian carcinoma cells. The fucosyltransferase activities from the cellular extracts of the four ovarian carcinoma cell lines were assayed using type 1 and type 2 oligosaccharides conjugated to a hydrophobic moiety as previously described (27). m130 and GG had higher FT activities against both type 2 and type 1 oligosaccharides than SKOV3 or OVM cells. These results agreed with the higher amounts of Lewis carbohydrate determinants detected on m130 and GG cells. Substitution of Galß4GlcNAc-R with Fuc $\alpha 2$-linked led to a 2.2-fold increase in $\alpha 3 \mathrm{FT}$ activity from m130 cells $\left(11.25 \pm 4.38 \mu \mathrm{U} / 1 \times 10^{6}\right.$ cells to $24.60 \pm 13.10 \mu \mathrm{U} /$ $1 \times 10^{6}$ cells) (Table I). However, substitution of Galß4GlcNAc$\mathrm{R}$ with NeuAca2,3-linked led to a 32-fold decrease in $\alpha 3 \mathrm{FT}$ activity from $\mathrm{m} 130$ cells $\left(11.25 \pm 4.38 \mu \mathrm{U} / 1 \times 10^{6}\right.$ cells to $0.35 \pm 0.14 \mu \mathrm{U} / 1 \times 10^{6}$ cells. These results indicated that the major $\alpha 3$ FT activity present in m130 cells involved in the synthesis of the $\mathrm{Le}^{\mathrm{x}}$ and $\mathrm{Le}^{\mathrm{y}}$ determinants would possibly consist of FUT9 or FUT4 (36). Although with lower a3 FT activities GG showed the same profile, which suggests that also for these cells FUT4 or FUT9 would be key enzymes for the synthesis of $\mathrm{Le}^{\mathrm{x}}$ and $\mathrm{Le}^{\mathrm{y}}$. The low activity observed against the sialylated type 2 acceptor in 130 and GG cells could be due either to FUT5 or FUT6 as detected by RT-PCR (Fig. 2). SKOV3 and OVM cells had only comparably lower $\alpha 3$ FT activity, but followed a similar profile.

Concerning $\alpha 4$ FT activity, we observed that substitution of Galß3GlcNAc-R with Fuca2-linked as acceptor led to a 3.7-fold increased $\alpha 4$ FT activity from GG cells $(2.90 \pm 0.17 \mu \mathrm{U} /$ $1 \times 10^{6}$ cells to $10.74 \pm 1.04 \mu \mathrm{U} / 1 \times 10^{6}$ cells) (Table I). However, substitution of Galß3GlcNAc-R with NeuAca2,3-linked led to a small decrease in GG $\alpha 4$ FT activity $(2.90 \pm 0.17 \mu \mathrm{U} /$ $1 \times 10^{6}$ cells to $2.67 \pm 0.40 \mu \mathrm{U} / 1 \times 10^{6}$ cells). These results suggested that FUT3 would be the enzyme involved in the synthesis of $\mathrm{Le}^{\mathrm{a}}$, sLe $\mathrm{SL}^{\mathrm{a}}$ and $\mathrm{Le}^{\mathrm{b}}$ in GG cells. There is a remote possibility that FUT5 would also participate in the synthesis of these determinants since it has a low activity towards type 1 
Table I. Substrate specificity of fucosyltranferases expressed in cancer cell lines. ${ }^{\mathrm{a}}$

\begin{tabular}{llcc}
\hline Substrate & Cell line & $\begin{array}{c}\text { Activity } \\
\left(\mu \mathrm{U} / 1 \times 10^{6} \text { cells }\right)\end{array}$ \\
\hline Type 1 acceptors & & & \\
Galß1,3GlcNAc-R & SKOV3 & 0 & 0 \\
& OVM & 0.04 & \pm 0.03 \\
& m130 & 0.38 & \pm 0.09 \\
& GG & 2.90 & \pm 0.17 \\
NeuAca2,3Galß1,3GlcNAc-R & SKOV3 & 0 & 0 \\
& OVM & 0 & 0 \\
& m130 & 0.14 & \pm 0.30 \\
& GG & 2.67 & \pm 0.40 \\
& SKOV3 & 0 & 0 \\
Fuc $\alpha 1,2$ Galß1,3GlcNAc-R & OVM & 0 & 0 \\
& m130 & 0.05 & \pm 0.03 \\
& GG & 10.74 & \pm 1.04
\end{tabular}

Type 2 acceptors

\begin{tabular}{llrc} 
Galß1,4GlcNAc-R & SKOV3 & 0.67 & \pm 0.16 \\
& OVM & 0.30 & \pm 0.24 \\
& m130 & 11.25 & \pm 4.38 \\
& GG & 2.27 & \pm 0.80 \\
NeuAca2,3Galß1,4GlcNAc-R & SKOV3 & 0 & 0 \\
& OVM & 0 & 0 \\
& m130 & 0.35 & \pm 0.14 \\
& GG & 0.15 & \pm 0.07 \\
Fuca1,2Galß1,4GlcNAc-R & SKOV3 & 0.76 & \pm 0.55 \\
& OVM & 1.08 & \pm 0.17 \\
& m130 & 24.60 & \pm 13.10 \\
& GG & 3.79 & \pm 0.12 \\
\hline
\end{tabular}

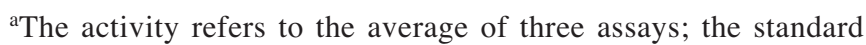
deviation is represented; $\mathrm{R}=-\left(\mathrm{CH}_{2}\right)_{3}-\mathrm{NHCO}-\left(\mathrm{CH}_{2}\right)_{5}-\mathrm{NH}$-biotin.

acceptors (6). m130 cells had only a low amount of $\alpha 4$ FT activity.

Detection of FUT3, FUT4, FUT5 and FUT9 in ovarian carcinoma cells. The results presented above clearly showed that GG and m130 cells expressed higher amounts of Lewis determinants and $\alpha 3 / 4$ fucosyltransferase activity. However, it was not clear which enzyme would be expressed and functional in each case. Therefore, we performed Western blot analysis for FUT3, FUT4, FUT5 and FUT9 of cell extracts from GG and m130 cells (Fig. 7). In GG cells, we observed higher amounts of FUT3 and FUT4, followed by FUT9, and FUT5 was almost not detected. The strong band at $42 \mathrm{kDa}$ from GG cells corresponded to FUT3 since heterologous expression of human FUT3 in these cells as well as m130 cells co-migrated with this band by Western

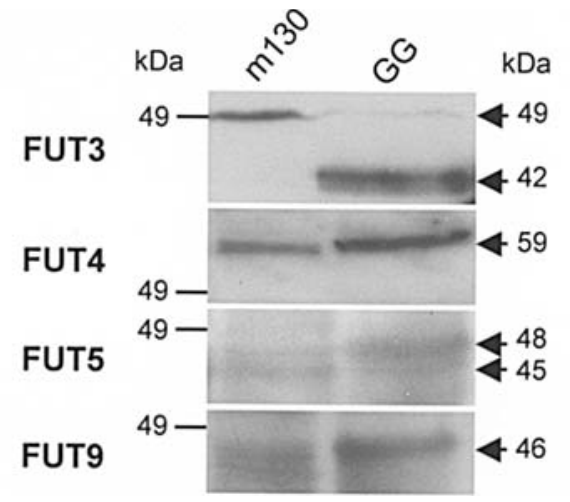

Figure 7. Western blot analysis of FUT3, FUT4, FUT5 and FUT9 in ovarian carcinoma cell lines. Total protein extracted from $1 \times 10^{6}$ cells of SKOV3, OVM, m130 and GG (indicated above the lanes) was applied in a 12\% acrylamide gel. As primary antibodies anti-human FUT3 SA-4817, FUT4 C-17, FUT5 N-18 and FUT9 C-20 polyclonal antibodies were used. The predicted molecular masses from their amino acid sequence of FUT3, FUT4, FUT5 and FUT9 are 42.1, 45.6, 43.0 and 42.0 kDa, respectively. Detection was performed with the ECL method.

blot analysis (data not shown). These results corroborated our previous conclusion that FUT3 was the enzyme involved in the synthesis of $\mathrm{Le}^{\mathrm{a}}$, sLe ${ }^{\mathrm{a}}$ and $\mathrm{Le}^{\mathrm{b}}$ in GG cells. FUT4 was detected at $59 \mathrm{kDa}$ that probably corresponded to the long form ELFT-L (predicted molecular mass $59 \mathrm{kDa}$ ) identified by Goelz et al (37). FUT9 whose predicted molecular mass from the amino acid sequence is $42 \mathrm{kDa}$, appeared at $46 \mathrm{kDa}$. This difference probably corresponded to post-translational modifications, most probably $\mathrm{N}$-glycosylation, since it is known that FUT9 has 3 potential N-glycosylation sites. Due to their relative abundances, we concluded that FUT4 and FUT9 were the enzymes involved in the synthesis of the Le ${ }^{\mathrm{x}}$ and $\mathrm{Le}^{\mathrm{y}}$ determinants in GG cells.

For m130 cells, a band at $49 \mathrm{kDa}$ was detected with the anti-FUT3 antibody. This band most probably consisted of non-specific binding of the antibody, since it appeared in all cell lines even when they did not have a4-FT activity (data not shown). FUT4 and FUT9 were detected in m130 cells, both of the enzymes probably synthesizing $\mathrm{Le}^{\mathrm{x}}$ and $\mathrm{Le}^{\mathrm{y}}$ in those cells.

\section{Discussion}

In the present study, we have characterized the expression of the fucosylated carbohydrate Lewis determinants from four ovarian carcinoma cell lines and identified the $\alpha 3 / 4$ FTs that underlie their synthesis. We have found that GG cells expressed high amounts of $\mathrm{Le}^{\mathrm{y}}, \mathrm{Le}^{\mathrm{x}}$, sLe $\mathrm{Le}^{\mathrm{a}}$ and $\mathrm{Le}^{\mathrm{b}}$, whereas m130 cells expressed $\mathrm{Le}^{\mathrm{x}}$ and $\mathrm{Le}^{\mathrm{y}}$. These cell lines have several glycosylation properties already described for ovarian cancer tissues, where it was found that mucinous tumors homogeneously expressed $\mathrm{Le}^{\mathrm{a}}$ and $\mathrm{sLe}^{\mathrm{a}}$ whereas serous and endometrioid tumors strongly expressed $\mathrm{Le}^{\mathrm{y}}$ and $\mathrm{H}$ type 2 antigen (38).

These carbohydrate determinants were abundantly detected on multiple projections of the cell surface (Fig. 5). This localization was likely associated with their role in cell adhesion events occurring during hematogenous metastases where they can serve as ligands for P- and E-selectin (reviewed in ref. 2). 
However, we cannot exclude that they might participate in cell adhesion events within the tumor through carbohydratemediated homophilic interaction. They were also detected in intracellular vesicles and corresponded to the Lewis containing glycolipids or glycoproteins in transit to the plasma membrane. The high amount observed of those structures indicated the high turnover of the plasma membrane.

The final steps in the synthesis of the Lewis determinants are catalysed by different $\alpha 3 / 4$ FTs. Identification of which FUTs are involved in this process provides a means for regulating their expression. We have used three strategies to detect the expression of $\alpha 3 / 4$ FTs in ovarian carcinoma cells: RT-PCR, fucosyltransferase activity against a panel of substrate acceptors and Western blotting, since each of these techniques has its own limitations. RT-PCR is not quantitative and very low amounts of mRNA might not be detected; on the other hand, if regulation occurs downstream of transcription, there might be a signal on RT-PCR but no protein will be translated. It is usually possible to identify an FT based on a characteristic profile of activity against an array of acceptors, if the FT is pure; when dealing with cellular extracts the profiles obtained might be altered. Finally, Western blotting is sometimes not sensitive or specific enough.

Our RT-PCR results showed that all ovarian carcinoma cell lines studied expressed FUT4, FUT5 and FUT6 transcripts. FUT3 was expressed at lower levels in SKOV3, followed by GG and m130 cells. Furthermore, several ovarian cancer tissues expressed the same transcripts. However, FUT3, FUT5 and FUT6 were not detected by RT-PCR or Northern blotting on normal ovary tissue (39). Therefore, the expression of FUT3, FUT5 and FUT6 could be a useful indication of an ovarian carcinoma. The fact that only a fraction of the analysed tissues expressed these three FTs may stem from the different origins and stages of the tumours. We have also observed that only one of the tissues analysed with a lower grade of progression (G2x) expressed only FUT6. Furthermore, FUT4 was found in more tissues with a higher grade of progression (G3x). This indicates that concomitantly to carcinoma progression FT transcription, namely FUT3, FUT4, FUT5, FUT6 and FUT9 could be increased. The variation of the profile of FTs expressed by each tumor might be due to a cell heterogeneity of the carcinomas that reflects a variable representation of the cell type.

The RT-PCR of FUT3, FUT4, FUT5, FUT6, FUT9 and FUT10 profiles was very similar for the different cell lines (Fig. 2). However, the Lewis determinants were predominantly detected in GG cells followed by $\mathrm{m} 130$ as detected by FACS analysis (Fig. 4) and immunofluorescence microscopy (Fig. 5). These results essentially agreed with those obtained for $\alpha 3 / 4$ FT activities where GG and m130 cells had higher values than SKOV3 and OVM cells (Table I). These results indicated that even if the $\alpha 3 / 4$ FT mRNA were present in SKOV3 and OVM cells, there was a downstream regulating mechanism that prevented synthesis of the corresponding proteins. Furthermore, SKOV3 and OVM cells probably have a set of acceptors and glycosyltransferases in a distinct organization along the Golgi apparatus that resulted in a distinct glycosylation pattern. For example, SKOV3 and OVM cells contained more Galß3GalNAc from $O$-linked glycoproteins, and SKOV3 cells contained more terminal NeuAc, than the remaining cells
(Fig. 6). These epitopes could respectively correspond to the carbohydrate determinants $\mathrm{T}$ sialyl or Tn that are known to be increased in ovarian carcinoma (reviewed in ref. 3).

The results obtained from the in vitro $\alpha 3 / 4$ FT activities (Table I) together with the Western blot analysis (Fig. 7) suggested that FUT4 and FUT9 could participate in the synthesis of $\mathrm{Le}^{\mathrm{x}}$ and $\mathrm{Le}^{\mathrm{y}}$ in GG as well as in m130 cells. Furthermore, the results suggested that FUT3 was responsible for the synthesis of $\mathrm{Le}^{\mathrm{a}}, \mathrm{sLe}^{\mathrm{a}}$ and $\mathrm{Le}^{\mathrm{b}}$ in GG cells. Previous studies (19) on the expression of $\alpha 3 / 4$ FTs in tumors of ovarian cancer showed that the tumor contained two major identifiable activities. One particular enzyme acted on H-type 2 and its activity was decreased to $20 \%$ and $2 \%$ when the type 2 acceptors were terminally substituted with sulfo 3 - or NeuAca2,3-linked, respectively. This activity probably corresponded to FUT4, the myeloid enzyme. The high decrease in $\alpha 3$ FT activity upon substitution of the type 2 acceptor by sulfate is a characteristic of FUT9 (40), an enzyme that had not been characterized at that time. Therefore, it is possible that besides FUT4, FUT9 could also be found in the ovarian tumor described by those authors. Another activity that was associated with the soluble tumor fraction resembled FUT3, the Lewis enzyme, because it acted preferentially on type 1 acceptors. Interestingly, these authors showed that the ratio in $\alpha 4$ FT activity towards the 2-methyl Galß1,3GlcNAcß-Obenzyl between ovarian tumor and normal ovarian tissue extracts, ranged between 3- and 141-fold. This indicated an association between the Lewis enzyme activity and tumor development. In some of the ovarian cancer tissues analysed in the present work by RT-PCR we also observed the expression of FUT3, FUT4 and FUT9.

In conclusion, we found that GG cells expressed high levels of $\mathrm{Le}^{\mathrm{x}}, \mathrm{Le}^{\mathrm{y}}, \mathrm{sLe}^{\mathrm{a}}$ and $\mathrm{Le}^{\mathrm{b}}$, whereas $\mathrm{m} 130$ cells expressed high levels of $\mathrm{Le}^{\mathrm{x}}$ and $\mathrm{Le}^{\mathrm{y}}$. $\mathrm{Le}^{\mathrm{x}}$ and $\mathrm{Le}^{\mathrm{y}}$ were synthesized by FUT4 and FUT9, whereas sLe ${ }^{\mathrm{a}}$ and $\mathrm{Le}^{\mathrm{b}}$ were synthesized by FUT3. These have been found to be major activities associated with ovarian carcinoma (19). Therefore, GG and m130 cells constitute adequate models to study the role of Lewis determinants on ovarian tumor progression and metastasis formation, which could be accomplished by silencing the corresponding fucosyltransferases.

\section{Acknowledgements}

This work was funded by grant LSHG-CT-2004-503228 from the European Commission. We thank Dr Harald Conradt and Dr Eckart Grabenhorst, GlycoThera, Braunschweig, Germany for the gift of pCRFT4 and pCRFT7 vectors. We thank Professor Henrik Clausen and Dr Ulla Mandel, University of Copenhagen, Denmark, for monoclonal antibodies FH6, AH6, and SH1.

\section{References}

1. Auersperg N, Wong AS, Choi KC, et al: Ovarian surface epithelium: biology, endocrinology, and pathology. Endocr Rev 22: 255-288, 2001 .

2. Becker DJ and Lowe JB: Fucose: biosynthesis and biological function in mammals. Glycobiology 13: 41R-53R, 2003.

3. Dube DH and Bertozzi CR: Glycans in cancer and inflammation - potential for therapeutics and diagnostics. Nat Rev Drug Discov 4: 477-488, 2005. 
4. Kukowska-Latallo JF, Larsen RD, Nair RP, et al: A cloned human cDNA determines expression of a mouse stagespecific embryonic antigen and the Lewis blood group $\alpha(1,3 / 1,4)$ fucosyltransferase. Genes Dev 4: 1288-1303, 1990.

5. Lowe JB, Kukowska-Latallo JF, Nair RP, et al: Molecular cloning of a human fucosyltransferase gene that determines expression of the Lewis $\mathrm{x}$ and VIM-2 epitopes but not ELAM-1dependent cell adhesion. J Biol Chem 266: 17467-17477, 1991.

6. Weston BW, Nair RP, Larsen RD, et al: Isolation of a novel human $\alpha(1,3)$ fucosyltransferase gene and molecular comparison to the human lewis blood group $\alpha(1,3 / 1,4)$ fucosyltransferase gene. Syntenic, homologous, nonallelic genes encoding enzymes with distinct acceptor substrate specificities. J Biol Chem 267: 4152-4160, 1992.

7. Weston BW, Smith PL, Kelly RJ, et al: Molecular cloning of a fourth member of a human $\alpha(1,3)$ fucosyltransferase gene family. Multiple homologous sequences that determine expression of the Lewis x epitopes. J Biol Chem 267: 24575-24584, 1992.

8. De Vries T, Srnka CA, Palcic MM, et al: Acceptor specificity of different length constructs of human recombinant alpha 1,3/ 4 -fucosyltransferases. Replacement of the stem region and the transmembrane domain of fucosyltransferase $\mathrm{V}$ by protein $\mathrm{A}$ results in an enzyme with GDP-fucose hydrolyzing activity. J Biol Chem 270: 8712-8722, 1995.

9. Natsuka S, Gersten KM, Zenita K, et al: Molecular cloning of a cDNA encoding a novel human leukocyte alpha-1,3fucosyltransferase capable of synthesizing the sialyl Lewis $\mathrm{x}$ determinant. J Biol Chem 269: 16789-16794, 1994.

10. Kaneko M, Kudo T, Iwasaki H, et al: Alpha1,3-fucosyltransferase IX (Fuc-TIX) is very highly conserved between human and mouse; molecular cloning, characterization and tissue distribution of human Fuc-TIX. FEBS Lett 452: 237-242, 1999.

11. Roos C, Kolmer M, Mattila P, et al: Composition of Drosophila melanogaster proteome involved in fucosylated glycan metabolism. J Biol Chem 277: 3168-3175, 2002.

12. Baboval T and Smith FI: Comparison of human and mouse Fuc-TX and Fuc-TXI genes, and expression studies in the mouse. Mamm Genome 13: 538-541, 2002.

13. Ogawa J, Inoue H and Koide S: Expression of alpha-1,3fucosyltransferase type IV and VII genes is related to poor prognosis in lung cancer. Cancer Res 56: 325-329, 1996.

14. Petretti T, Schulze B, Schlag PM, et al: Altered mRNA expression of glycosyltransferases in human gastric carcinomas. Biochim Biophys Acta 1428: 209-218, 1999.

15. Petretti T, Kemmner W, Schulze B, et al: Altered mRNA expression of glycosyltransferases in human colorectal carcinomas and liver metastases. Gut 46: 359-366, 2000.

16. Mas E, Pasqualini E, Caillol N, et al: Fucosyltransferase activities in human pancreatic tissue: comparative study between cancer tissues and established tumoral cell lines. Glycobiology 8: 605-613, 1998

17. Numahata K, Satoh M, Handa K, et al: Sialosyl-Le(x) expression defines invasive and metastatic properties of bladder carcinoma. Cancer 94: 673-685, 2002.

18. Breton C, Oriol R and Imberty A: Conserved structural features in eukaryotic and prokaryotic fucosyltransferases. Glycobiology 8: 87-94, 1998.

19. Chandrasekaran EV, Jain RK and Matta KL: Ovarian cancer alpha 1,3-L-fucosyltransferase. Differentiation of distinct catalytic species with the unique substrate, 3 '-sulfo-N-acetyllactosamine in conjunction with other synthetic acceptors. J Biol Chem 267: 23806-23814, 1992.

20. Costa J, Grabenhorst E, Nimtz M, et al: Stable expression of the Golgi form and secretory variants of human fucosyltransferase III from BHK-21 cells. J Biol Chem 272: 11613-11621, 1997.

21. Grabenhorst E, Nimtz M, Costa J, et al: In vivo specificity of human $\alpha 1,3 / 4$-fucosyltransferases III-VII in the biosynthesis of Lewis X and sialyl Lewis X motifs on complex-type N-glycans: coexpression studies from BHK-21 cells together with human B-trace protein. J Biol Chem 273: 30985-30994, 1998.
22. Kudo T, Ikehara Y, Togayachi A, et al: Up-regulation of a set of glycosyltransferase genes in human colorectal cancer. Lab Invest 78: 797-811, 1998.

23. Fukushi Y, Nudelman E, Levery SB, et al: Novel fucolipids accumulating in human adenocarcinoma. III. A hybridoma antibody (FH6) defining a human cancer-associated difucoganglioside (VI3NeuAcV3III3Fuc2nLc6). J Biol Chem 259: 10511-10517, 1984

24. Fukushi Y, Hakomori S, Nudelman E, et al: Novel fucolipids accumulating in human adenocarcinoma. II. Selective isolation of hybridoma antibodies that differentially recognize mono-, di-, and trifucosylated type 2 chain. J Biol Chem 259: 4681-4685, 1984.

25. Abe K, McKibbin JM and Hakomori S: The monoclonal antibody directed to difucosylated type 2 chain (Fuc alpha 1 leads to $2 \mathrm{Gal}$ beta 1 leads to 4 [Fuc alpha 1 leads to 3$] \mathrm{GlcNAc}$ Y Determinant). J Biol Chem 258: 11793-11797, 1983.

26. Gast D, Riedle S, Riedle S, et al: L1 augments cell migration and tumor growth but not beta3 integrin expression in ovarian carcinomas. Int J Cancer 115: 658-665, 2005.

27. Morais VA, Serpa J, Palma AS, et al: Expression and characterization of recombinant human alpha-3/4- fucosyltransferase III from Spodoptera frugiperda (Sf9) and Trichoplusia ni (Tn) cells using the baculovirus expression system. Biochem J 353: 719-725, 2001 .

28. Faye L and Chrispeels MJ: Characterization of N-linked oligosaccharides by affinoblotting with concanavalin A-peroxidase and treatment of the blots with glycosidases. Anal Biochem 149: 218-224, 1985

29. Singhal AK, Orntoft TF, Nudelman E, et al: Profiles of Lewisxcontaining glycoproteins and glycolipids in sera of patients with adenocarcinoma. Cancer Res 50: 1375-1380, 1990.

30. Fukui S, Feizi T, Galustian C, et al: Oligosaccharide microarrays for high-throughput detection and specificity assignments of carbohydrate-protein interactions. Nat Biotechnol 20: 1011-1017, 2002.

31. Montreuil J, Bouquelet S, Debray H, et al: Carbohydrate analysis - a practical approach. Rickwood D and Hames BD (eds). IRL Press, Oxford, 2003

32. Fu D, Chen L and O'Neill RA: A detailed structural characterization of ribonuclease B oligosaccharides by $1 \mathrm{H}$ NMR spectroscopy and mass spectrometry. Carbohydr Res 261: 173-186, 1994.

33. Edge AS and Spiro RG: Presence of an O-glycosidically linked hexasaccharide in fetuin. J Biol Chem 262: 16135-16141, 1987.

34. Rice KG, Rao NB, and Lee YC: Large-scale preparation and characterization of $\mathrm{N}$-linked glycopeptides from bovine fetuin. Anal Biochem 184: 249-258, 1990.

35. Spik G, Bayard B, Fournet B, et al: Studies on glycoconjugates. LXIV. Complete structure of two carbohydrate units of human serotransferrin. FEBS Lett 50: 296-299, 1975

36. Cailleau-Thomas A, Coullin P, Candelier JJ, et al: FUT4 and FUT9 genes are expressed early in human embryogenesis. Glycobiology 10: 789-802, 2000 .

37. Goelz SE, Hession C, Goff D, et al: ELFT: A gene that directs the expression of an ELAM-1 ligand. Cell Press 63: 1349-1356, 1990

38. Federici MF, Kudryashov V, Saigo PE, et al: Selection of carbohydrate antigens in human epithelial ovarian cancers as targets for immunotherapy: serous and mucinous tumors exhibit distinctive patterns of expression. Int J Cancer 81: 193-198, 1999.

39. Cameron HS, Szczepaniak D and Weston BW: Expression of human chromosome 19p alpha(1,3)-fucosyltransferase genes in normal tissues. Alternative splicing, polyadenylation, and isoforms. J Biol Chem 270: 20112-20122, 1995.

40. Cailleau-Thomas A, Coullin P, Candelier JJ, et al: FUT4 and FUT9 genes are expressed early in human embryogenesis. Glycobiology 10: 789-802, 2000. 